\title{
Physical, chemical and microbial analysis of bottled drinking water
}

\author{
S Sasikaran ${ }^{1}$, K Sritharan ${ }^{2}$, S Balakumar ${ }^{2}$, V Arasaratnam ${ }^{2}$ \\ (Index words: physical parameters, calcium, nitrate, aerobic plate count and coliform bacteria)
}

\begin{abstract}
Introduction People rely on the quality of the bottled drinking water, expecting it to be free of microbial contamination and health hazards.
\end{abstract}

Objectives To evaluate the quality of bottled drinking water sold in Jaffna peninsula by analysing the physical, chemical and microbial contents and comparing with the recommended Sri Lankan Standard (SLS) values.

Methods All bottled water samples sold in Jaffna peninsula were collected. Electrical conductivity, total dissolved solid, $\mathrm{pH}$, calcium, nitrate, total aerobic and anaerobic count, coliform bacterial count and faecal contamination were checked.

Results These are 22 brands of bottled drinking water sold in Jaffna peninsula. The sample had very low electrical conductivity when compared with SLS $(750 \mu \mathrm{S} /$ $\mathrm{cm}$ ) and varied from 19 to $253 \mu \mathrm{S} / \mathrm{cm}$ with the mean of $80.53( \pm 60.92) \mu \mathrm{S} / \mathrm{cm}$. The $\mathrm{pH}$ values of the bottled drinking water brands varied from 4.11 to 7.58 with a mean of $6.2( \pm 0.75)$. The total dissolved solid content of the bottled drinking water brands varied from 9 to 123.67 $\mathrm{mg} / \mathrm{l}$ with a mean of $39.5( \pm 30.23) \mathrm{mg} / \mathrm{l}$. The calcium content of the bottled drinking water brands varied from 6.48 to $83.77 \mathrm{mg} / \mathrm{l}$ with a mean of $49.9( \pm 25.09) \mathrm{mg} / \mathrm{l}$. The nitrate content of the bottled drinking water brands varied from 0.21 to $4.19 \mathrm{mg} / \mathrm{l}$ with the mean of $1.26( \pm 1.08)$ $\mathrm{mg} / \mathrm{l}$. Aerobic bacterial count varied from 0 to 800 colony forming unit per $\mathrm{ml}(\mathrm{cfu} / \mathrm{ml})$ with a mean of 262.6 $( \pm 327.50) \mathrm{cfu} / \mathrm{ml}$. Among the 22 drinking bottled water brands 14 and $9 \%$ of bottled drinking water brands showed fungal and coliform bacterial contaminants respectively. The water brands which contained faecal contamination had either Escherichia coli or Klebsiella spp.

Conclusions The bottled drinking water available for sale do not meet the standards stipulated by SLS.

Ceylon Medical Journal 2012; 57: 111-116

\section{Introduction}

Water is the most important resource for humans. It forms 50 to $60 \%$ of body weight and play an active role in all the vital processes of our body [1]. The chemical quality of drinking water during recent years has deteriorated considerably due to the presence of toxic elements, which even in trace amounts can cause serious health hazards [2]. Water should be free from any organisms. But unfortunately water is not always found pure. The contamination of natural water with faecal material, domestic and industrial sewage and agricultural and pasture run off may result in an increased risk of disease transmission to humans [3]. The market is inundated with a large number of brands of bottled water. Various countries have enforced drinking water standards for the maximum permissible levels of different constituents [4]. Due to increased demand and consumption of bottled water in Sri Lanka, there has been a growing concern about the quality of these products. In recent times concerns have been expressed about the increase in poor quality of well

${ }^{1}$ Department of Agricultural Chemistry, Faculty of Agriculture and ${ }^{2}$ Department of Biochemistry, Faculty of Medicine, University of Jaffna, Sri Lanka.

Correspondence: SS, e-mail <sasit_agri@yahoo.com>. Received 22 March and revised version accepted 19 May 2012. Competing interests: none declared. 
water due to the nitrate pollution through continuous and liberal use of organic manure and inorganic fertilizers [5]. Therefore recently consumption of bottled water has been increasing. But, the quality of bottled water used for human consumption is not subjected to any stringent quality control measures. Hence this study was made to analyse the microbial contamination, physical properties and chemical contents in different brands of bottled water sold in Jaffna peninsula.

\section{Methods}

Materials used were as follows. Potato dextrose agar, Nutrient agar, Technical agar, MacConkey broth medium, Brilliant-green bile lactose broth medium, Tryptone water and Kligler Iron Agar medium were from Oxoide, England and Simmon's citrate dehydrated medium as from BioMerieux, France. o-Cresolphthalein complexone, 8Hydroxyquinoline, Ethanediol, 2-amino-2 methyl-1proponol, calcium carbonate, Brucine solution, Potassium nitrate and $\mathrm{CHCl}_{3}$ were from $\mathrm{BDH}$, England. Bottled drinking water samples available in Jaffna peninsula were collected and analysed.

The Electrical Conductivity (EC) and Total Dissolved Solid (TDS) were measured with a conductivity meter (inoLab cond level 1) for analysis. The $\mathrm{pH}$ values of the bottled water samples were measured with a $\mathrm{pH}$ meter (Thermo Orion Model $420 \mathrm{~A}^{+}$). WHO Recommended ocresolphthalein complexone method and Brucine method were used to measure the calcium content and nitrate contents respectively $[6,7]$.

Potato Dextrose Agar (PDA) medium and nutrient agar medium were used to test fungal and bacterial contamination respectively [8]. Fungal contamination was determined by spread plate method. The mycelium was examined under the digital microscope to determine the genus and aerobic bacterial count was determined by spread plate method and anaerobic bacterial counts determined by pour plate method $[8,9]$. Coliform bacteria contamination was tested with presumptive test using MacConkey broth medium and the coliform bacterial contamination was confirmed with brilliant-green bile lactose broth [10]. The standard methods were used to confirm the contaminations as E.coli and Kellebsiela [8].

Descriptive statistics were applied to determine the mean values and standard deviations. Statistical analysis was performed using Minitab program version 13.0 and SAS program version 8.0. The Duncan's Multiple Comparisons Test was applied to determine significant differences in mean values. The level of significance was considered at $\mathrm{p}<0.05$.

\section{Results}

Three bottles of each brand ( 1.51 bottles) were brought from randomly selected grocery stores in Jaffna peninsula. A total of 22 brands (such as A, B, C, D, E, F, G, H, I, J, K, L, M, N, O, P, Q, R, S, T, V and U) were analysed. All samples selected for this study were stored at room temperature $\left(25-30^{\circ} \mathrm{C}\right)$ and the samples analysed were within 1-6 months of the date of manufacture (Table 1).

Total dissolved solid (TDS) content of 22 different brands of bottled water samples varied from 9.0 to 123.7 $\mathrm{mg} / \mathrm{l}$ with the mean of $39.5( \pm 29.79) \mathrm{mg} / \mathrm{l}$ (Table 2$).$ SLS recommends that a bottled drinking water can have TDS upto $1000 \mathrm{mg} / 1$ [11]. EC content of the 22 different brands of water samples varied from 19 to $253 \mu \mathrm{S} / \mathrm{cm}$ (mean value was $80.53( \pm 60.92) \mu \mathrm{S} / \mathrm{cm}$; Table 1) and the SLS recommends the EC of $750 \mu \mathrm{S} / \mathrm{cm}$ (Sri Lankan Standard $894,2003)$. The $\mathrm{pH}$ values of the 22 different brands of bottled water samples varied from 4.1 to 7.6 with the mean of $6.2( \pm 0.75)$ (Table 1$)$ and the recommendation is 6.5 to $8.5[11]$.

\section{Calcium and nitrate contents of different brands of bottled drinking water}

Calcium content of the water samples varied from 19 to $253 \mathrm{mg} / \mathrm{l}$ with the mean of $80.5( \pm 60.92) \mathrm{mg} / \mathrm{l}$ (Table 1$)$ and the SLS permits the calcium content upto $100 \mathrm{mg} / 1$ [11]. Nitrate content of the water samples varied from 0.22 to $4.19 \mathrm{mg} / \mathrm{l}$ and the mean value was $1.27( \pm 1.09) \mathrm{mg} / \mathrm{l}$ (Table 1) and the SLS recommended value is $50 \mathrm{mg} / 1$ [11].

\section{Fungal contamination}

Of the 22 bottled drinking water brands tested, three brands (A, K and L) of bottled water samples contained fungal contamination. When the mycelium was observed under the microscope, nonseptate hyphae with broad, irregular walls and branches that form more or less at right angles was observed. This indicated that the brand $\mathrm{K}$ had Mucor spp contamination. Brands A and L had colonies with powdery appearance. When the mycelium was observed under the microscope, the hyphae were branched and septate. This indicated that the brands A and L had Aspergillus spp contamination.

\section{Bacterial contamination}

Table 1 shows the aerobic bacterial count present in different brands of bottled water samples. Total aerobic count varied from 0 to $800 \mathrm{cfu} / \mathrm{ml}$. Among the bottled water brands $\mathrm{E}$ and $\mathrm{G}$ did not have aerobic bacterial contamination. The C, D, I, Q, T and U brands contained aerobic bacterial contamination less than the minimum level recommended by SLS $\left(1 \times 10^{2} \mathrm{cfu} / \mathrm{ml}\right)$. The A, B, F, H, J, K, $\mathrm{L}, \mathrm{M}, \mathrm{N}, \mathrm{O}, \mathrm{P}, \mathrm{R}, \mathrm{S}$ and $\mathrm{V}$ brands contained higher aerobic bacterial contamination than the recommended value of SLS [11]. The water samples which gave positive results for aerobic bacterial count were tested for coliform bacterial contamination. None of the bottled drinking water brands contained anaerobic bacterial growth. 
Table 1. Source, physical, mineral constituents, aerobic bacterial count and results of presumptive test of different brands of bottled drinking water

\begin{tabular}{|c|c|c|c|c|c|c|c|c|c|}
\hline \multirow[t]{2}{*}{ Brands } & \multirow[t]{2}{*}{ Source } & \multicolumn{3}{|c|}{ Physical constituents } & \multicolumn{2}{|c|}{ Mineral constituents } & \multirow{2}{*}{$\begin{array}{c}\text { Aerobic } \\
\text { microbial } \\
\text { count } \\
(c f u / m l) \\
\end{array}$} & \multicolumn{2}{|c|}{$\begin{array}{c}\text { Presumptive } \\
\text { test }\end{array}$} \\
\hline & & $\begin{array}{c}E C \\
\mu S / C M\end{array}$ & $\begin{array}{l}T D S \\
m g / l\end{array}$ & $p H$ & Calcium & Nitrate & & $G P$ & $A P$ \\
\hline A & Tube well & $97.4( \pm 0.3)$ & 48.0 & $6.6( \pm 0.59)$ & $25.0( \pm 0.95)$ & $0.29( \pm 0.04)$ & $216.7( \pm 288)$ & - & + \\
\hline B & Tube well & $69.2( \pm 0.15)$ & 34.0 & $6.5( \pm 0.06)$ & $26.9( \pm 5.55)$ & $0.85( \pm 0.14)$ & $312.5( \pm 403)$ & - & - \\
\hline $\mathrm{C}$ & Mountain spring & $71.2( \pm 0.26)$ & 35.0 & $6.6( \pm 0.07)$ & $29.9( \pm 2.9)$ & $0.72( \pm 0.16)$ & $55.7( \pm 41.17)$ & + & + \\
\hline $\mathrm{D}$ & Bore hole & $68.3( \pm 0.25)$ & $33.7( \pm 0.58)$ & $6.9( \pm 0.06)$ & $8.5( \pm 2.18)$ & $0.73( \pm 0.09)$ & $40.0( \pm 40.82)$ & + & + \\
\hline $\mathrm{E}$ & Dug well & $37.1( \pm 11.84)$ & $18.0( \pm 6.08)$ & $6.2( \pm 0.03)$ & $7.0( \pm 3.99)$ & $0.27( \pm 0.05)$ & Nil & - & - \\
\hline $\mathrm{F}$ & Dug well & $30.7( \pm 1.38)$ & $15.3( \pm 0.58)$ & $6.0( \pm 0.32)$ & $6.5( \pm 2.59)$ & $0.24( \pm 0.04)$ & $440.0( \pm 161)$ & - & + \\
\hline $\mathrm{G}$ & Dug well & $22.6( \pm 0.15)$ & 11.0 & $5.2( \pm 0.22)$ & $69.3( \pm 1.42)$ & $0.21( \pm 0.07)$ & Nil & - & - \\
\hline $\mathrm{H}$ & Dug well & $69.8( \pm 0.77)$ & $34.3( \pm 0.58)$ & $5.9( \pm 0.06)$ & $75.4( \pm 2.27)$ & $0.26( \pm 0.02)$ & $275.0( \pm 406)$ & + & + \\
\hline I & Spring water & $27.9( \pm 0.66)$ & 14.0 & $5.9( \pm 0.14)$ & $74.8( \pm 1.17)$ & $0.40( \pm 0.12)$ & $72.5( \pm 78)$ & - & - \\
\hline $\mathrm{J}$ & Dug well & $37.0( \pm 3)$ & $18.3( \pm 1.53)$ & $6.1( \pm 0.05)$ & $35.1( \pm 9.16)$ & $0.80( \pm 0.04)$ & $392.0( \pm 392)$ & - & + \\
\hline $\mathrm{K}$ & Dug well & $99.4( \pm 0.2)$ & 49.0 & $7.2( \pm 0.02)$ & $35.2( \pm 2.8)$ & $3.37( \pm 0.08)$ & 800.0 & - & - \\
\hline $\mathrm{L}$ & Tube well & $111.3( \pm 0.11)$ & 54.0 & $6.7( \pm 0.07)$ & $83.8( \pm 7.96)$ & $1.47( \pm 0.28)$ & $527.1( \pm 416)$ & - & - \\
\hline M & Tube well & $54.7( \pm 1.45)$ & $27.0( \pm 1)$ & $7.0( \pm 0.05)$ & $79.2( \pm 5.38)$ & $1.04( \pm 0.10)$ & $447.1( \pm 367)$ & - & - \\
\hline $\mathrm{N}$ & Natural spring & 35.2 & 17.0 & $5.6( \pm 0.07)$ & $65.5( \pm 4.05)$ & $2.48( \pm 0.62)$ & $267.5( \pm 363)$ & - & + \\
\hline $\mathrm{O}$ & Dug well & $82.5( \pm 0.75)$ & $40.7( \pm 0.58)$ & $6.0( \pm 0.06)$ & $42.4( \pm 4.45)$ & $1.18( \pm 0.04)$ & $277.5( \pm 353)$ & - & - \\
\hline $\mathrm{P}$ & Dug well & $124.4( \pm 0.74)$ & 61.0 & $6.2( \pm 0.07)$ & $73.5( \pm 0.44)$ & $2.13( \pm 0.19)$ & 110.0 & + & - \\
\hline Q & Underground spring & $189.6( \pm 4.14)$ & $93.0( \pm 1.73)$ & $7.6( \pm 0.08)$ & $68.1( \pm 2.34)$ & $0.74( \pm 0.04)$ & $53.3( \pm 48)$ & - & - \\
\hline $\mathrm{R}$ & Dug well & $32.2( \pm 0.14)$ & 16.0 & $5.2( \pm 0.10)$ & $65.0( \pm 2.69)$ & $2.31( \pm 0.28)$ & $196.7( \pm 303)$ & + & + \\
\hline $\mathrm{S}$ & Dug well & $19.0( \pm 0.3)$ & 9.0 & $4.1( \pm 0.05)$ & $61.2( \pm 0.67)$ & $1.08( \pm 0.06)$ & $718.8( \pm 229)$ & - & - \\
\hline $\mathrm{T}$ & Tube well & $191.5( \pm 7.39)$ & $93.7( \pm 4.04)$ & $6.5( \pm 0.05)$ & $73.5( \pm 0.76)$ & $0.81( \pm 0.06)$ & 20.0 & - & - \\
\hline $\mathrm{U}$ & Tube well & $47.7( \pm 3.56)$ & $123.7( \pm 0.58)$ & $6.8( \pm 0.05)$ & $50.3( \pm 22.45)$ & $4.19( \pm 0.06)$ & $31.1( \pm 257)$ & - & + \\
\hline $\mathrm{V}$ & Dug well & $253.0( \pm 1)$ & $23.3( \pm 1.53)$ & $6.1( \pm 0.03)$ & $42.0( \pm 3.55)$ & $2.30( \pm 0.09)$ & $115.6( \pm 25)$ & - & + \\
\hline
\end{tabular}

Mean of EC, TDS, pH, calcium, nitrate and aerobic bacterial count are $80.5( \pm 60.92), 39.5( \pm 30.23), 6.2( \pm 0.75), 49.9( \pm 25.09), 1.26( \pm 1.08)$ and $262.6( \pm 327.50)$ respectively.

GP and AP - Gas Production and Acid Production respectively.

Table 2. Results obtained for normal coliform confirmation test with bottled drinking water brands such as C, D, $H$ and $R$

\begin{tabular}{|c|c|c|c|c|c|c|c|c|c|c|c|c|c|c|c|c|c|c|}
\hline \multirow{3}{*}{$\begin{array}{l}\text { Brands } \\
\text { Volume }\end{array}$} & \multicolumn{9}{|c|}{ Results for normal coliform } & \multicolumn{9}{|c|}{ Results for faecal coliform } \\
\hline & \multicolumn{3}{|c|}{ Sample 1} & \multicolumn{3}{|c|}{ Sample 2} & \multicolumn{3}{|c|}{ Sample 3} & \multicolumn{3}{|c|}{ Sample 1} & \multicolumn{3}{|c|}{ Sample 2} & \multicolumn{3}{|c|}{ Sample 3} \\
\hline & $10 \mathrm{~mL}$ & $1 m L$ & $0.1 \mathrm{~mL}$ & $10 \mathrm{~mL}$ & $1 \mathrm{~mL}$ & $0.1 \mathrm{~mL}$ & $10 \mathrm{~mL}$ & $1 m L$ & $0.1 \mathrm{~mL}$ & $10 \mathrm{~mL}$ & $1 m L$ & $0.1 \mathrm{~mL}$ & $10 \mathrm{~mL}$ & $1 m L$ & $0.1 \mathrm{~mL}$ & $10 \mathrm{~mL}$ & $1 m L$ & $0.1 \mathrm{~mL}$ \\
\hline $\mathrm{C}$ & NP & $1 \mathrm{~T}$ & $\mathrm{NP}$ & NP & $1 \mathrm{~T}$ & NP & NP & $1 \mathrm{~T}$ & NP & NP & NP & NP & NP & $1 \mathrm{~T}$ & NP & NP & $1 \mathrm{~T}$ & NP \\
\hline $\mathrm{D}$ & $\mathrm{NP}$ & 2 Ts & NP & NP & NP & NP & NP & NP & NP & NP & $2 \mathrm{Ts}$ & NP & NP & NP & NP & NP & NP & NP \\
\hline $\mathrm{H}$ & NP & NP & NP & NP & NP & NP & NP & NP & NP & NP & NP & NP & NP & NP & NP & NP & NP & NP \\
\hline $\mathrm{R}$ & NP & NP & NP & NP & NP & NP & NP & NP & NP & NP & NP & NP & NP & NP & NP & NP & NP & NP \\
\hline
\end{tabular}

NP - No production of both gas and acid, T- Tube, Ts - Tubes

Table 3. Morphological characteristics of the bacterial strains isolated from different brands of bottled water sample in MacConkey agar plate, result of triple sugar iron agar test and citrate utilization test for bottled drinking water brands $C$ and $D$

\begin{tabular}{|c|c|c|c|c|c|c|c|c|c|c|}
\hline \multirow[t]{2}{*}{ Brands } & \multirow[t]{2}{*}{ Strain } & \multicolumn{4}{|c|}{ Morphological characters } & \multicolumn{2}{|c|}{ Triple sugar iron agar } & \multirow[b]{2}{*}{ Gas } & \multirow[b]{2}{*}{$\mathrm{H}_{2} \mathrm{~S}$} & \multirow{2}{*}{$\begin{array}{c}\text { Citrate } \\
\text { utilization }\end{array}$} \\
\hline & & Form & Elevation & Colour & Surface & Butt & Slope & & & \\
\hline $\mathrm{C}$ & $\mathrm{C} 1$ & Circular & Flat & Light Pink & Dry, shiny & Yellow & Yellow & + & - & - \\
\hline \multirow[t]{2}{*}{$\mathrm{D}$} & D 1 & Irregular & Convex & Pink & Moist & Light orange & Light orange & - & - & + \\
\hline & D2 & Circular & Convex & Pink & Moist & Light orange & Light orange & - & - & + \\
\hline
\end{tabular}

Only one type of strain was isolated from bottled drinking water brand $\mathrm{C}$ and denoted as strain $\mathrm{C}$.

Two strains with different morphological characteristics were isolated from bottled drinking water brand $\mathrm{D}_{\text {and }}$ denoted as strains $\mathrm{D}_{1}$ and $\mathrm{D}_{2}$. 
Table 4. Comparison of biochemical and other characteristics of Escherichia coli with strain $\mathrm{C}$ and Klebsiella with strain D1 \& D2

\begin{tabular}{|c|c|c|c|c|c|}
\hline Characters & $\begin{array}{c}\text { Characteristics of } \\
\text { Escherichia coli }\end{array}$ & $\begin{array}{c}\text { Characteristics of } \\
\text { strain } C\end{array}$ & $\begin{array}{c}\text { Characteristics of } \\
\text { Klebsiella }\end{array}$ & $\begin{array}{c}\text { Character } \\
D_{1}\end{array}$ & $\begin{array}{c}\text { of strains } \\
\mathrm{D}_{2}\end{array}$ \\
\hline Lactose fermentation & Positive & Positive & Negative & Negative & Negative \\
\hline Acid from glucose & Positive & Positive & Negative & Negative & Negative \\
\hline Utilization of citrate & Negative & Negative & Positive & Positive & Positive \\
\hline Production of indole & Positive & Positive & Negative & Negative & Negative \\
\hline
\end{tabular}

Only one type of strain was isolated from bottled drinking water brand $\mathrm{C}$ and is denoted as strain C.

Two strains with different morphological characteristics were isolated from bottled drinking water brand $\mathrm{D}_{\text {was }}$ denoted as strains $\mathrm{D}_{1}$ and $\mathrm{D}_{2}$.
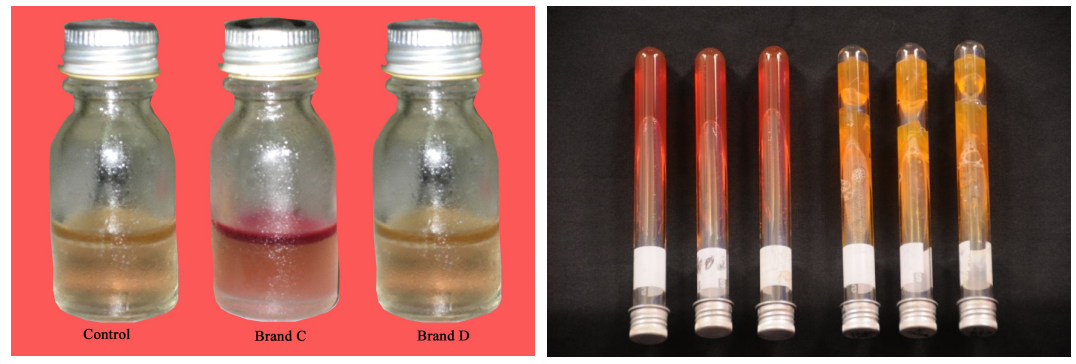

Plate 1 (a): Test for E.coli. Bottled Plate 2: Colour changes in Simmon's Plate 1 (b): Gas formation in Kligler iron drinking water brands $C$ and $D$ in citrate medium (Citrate test) due to agar medium (Triple Sugar Iron Agar tryptone water medium. the growth of the organisms in Test) by the organisms in bottled bottled drinking water brand $D$. drinking water brand $\mathrm{C}$.

Tubes C1, C2 and C3 are tests; Tubes C1, C2 and C3 are control; Tubes Tubes T1, T2 and T3 are control. T1, T2 and T3 are test.

\section{Testing for coliform bacteria and its confirmation}

Presumptive test was performed to all the bottled water samples which gave positive results to bacterial contamination. Bottled water brands C, D, H and R showed positive results (that is both gas and acid production for the presumptive test) (Table 1). This indicated the possible contamination of coliform bacteria. Bottled water brands $\mathrm{A}, \mathrm{F}, \mathrm{J}, \mathrm{M}, \mathrm{N}, \mathrm{U}$ and $\mathrm{V}$ produced only acid but brand $\mathrm{P}$ produced only gas. Brands B, E, G, I, K, L, O, Q, S and T did not produce gas and acid. The coliform bacteria produce both gas and acid in presumptive test [10]. Therefore it was concluded that brands A, B, E, F, G, I, J, K, L, M, N, O, P, Q, S, T, U and V were free from coliform bacterial contamination.

Presence of coliform bacterial contamination in the bottled water brands $\mathrm{C}, \mathrm{D}, \mathrm{H}$ and $\mathrm{R}$ was confirmed by conducting Brilliant green bile lactose broth test. The water brands $\mathrm{C}$ and $\mathrm{D}$ have shown both gas and acid production at $37^{\circ} \mathrm{C}$ for 48 hours that is indicating the presence of normal coliform bacterial contamination (Table 2). Brands $\mathrm{H}$ and $\mathrm{R}$ did not show positive results to confirmation test for normal coliform bacteria. All three samples ( 1 tube of $1.0 \mathrm{ml}$ out of 5 tubes answered positively) of brand $\mathrm{C}$ and sample 1 ( 2 tubes of $1.0 \mathrm{ml}$ out of 5 tubes positively answered) of brand D gave positive result to normal coliform test. Water samples $\mathrm{C}$ and $\mathrm{D}$ have shown both gas and acid production at $44^{\circ} \mathrm{C}$ for 24 hours that is indicating the presence of a faecal coliform (Table 2). Brands $\mathrm{H}$ and $\mathrm{R}$ did not show positive results to the confirmation test of faecal coliform bacteria. Samples 2 and 3 ( 1 tube of $1.0 \mathrm{ml}$ out of 5 tubes answered positively) of brand $\mathrm{C}$ and sample 1 ( 2 tubes of $1.0 \mathrm{ml}$ out of 5 tubes answered positively) of brand $\mathrm{D}$ gave positive result to normal coliform test.

\section{Identification of Escherichia coli and Klebsiella}

The results showed that the lactose fermenting different strains were present only in brands $\mathrm{C}$ (one strain C) and D (two strains, $\mathrm{D}_{1}$ and $\mathrm{D}_{2}$ ) (Table 3 ). Other brands of bottled drinking water did not have lactose fermenting strains. Different morphological characteristics of the strains were observed and used to differentiate the strains of the same brand. Only one type of lactose fermenting colony was identified from brand C. The colony had the morphological characteristics of round form, flat type elevation, pink in colour and dry surface. Morphological characteristics of strain $\mathrm{C}$ was analogous to Escherichia coli and strains $\mathrm{D}_{1}$ and $\mathrm{D}_{2}$ were analogous to Kellebsiela. The brand D contained two different types of lactose fermenting colonies. First type of colony had the morphological characteristics of irregular form, convex type elevation, dark pink colour and moist surface $\left(D_{1}\right)$. The second type colony had round form, convex type elevation, light pink colour and moist surface and named as $\mathrm{D}_{2}$. 


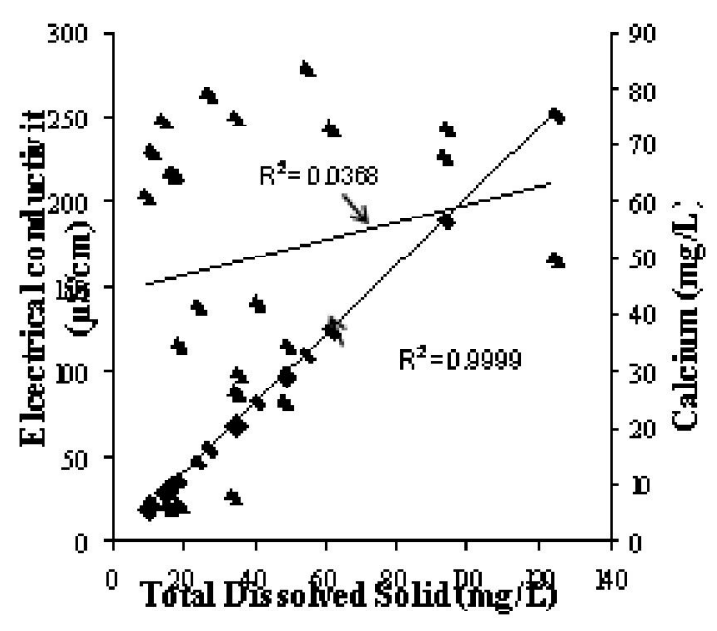

Figure 1 (a): Correlation between total dissolved solid and (") electrical conductivity and (?) calcium content of bottled drinking water brands.

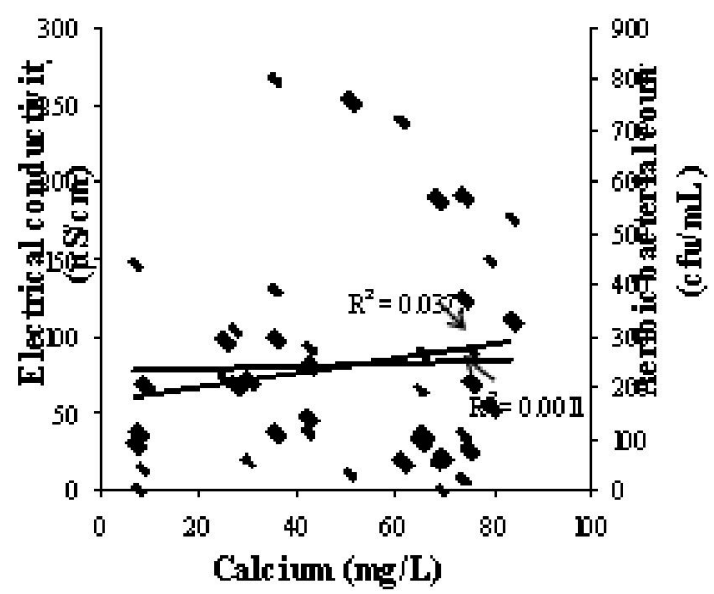

Figure 1 (b): Correlation between calcium and (") electrical conductivity and aerobic bacterial count (o) of bottled drinking water brands.

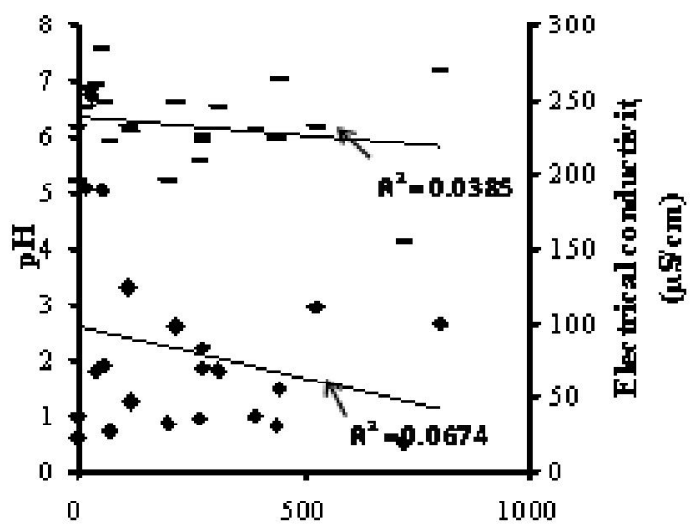

Aer obic bacterial c ownt (r fu'mL)

Figure 1 (c): Correlation between aerobic bacterial count and electrical conductivity (") and pH (-) of bottled drinking water brands.
Strain $\mathrm{C}$ produced indole production and suspected as E.coli [Plate 1(a)]. To confirm the strain C as E.coli, triple sugar iron agar test was carried out. Only strain C had given positive result to Triple Sugar Iron Agar test (Table 3) [Plate 1(b)] while strains $\mathrm{D}_{1}$ and $\mathrm{D}_{2}$ from brand D gave negative results. The strains $\mathrm{D}_{1}$ and $\mathrm{D}_{2}$ from brand D utilized citrate as their carbon source. Growth of bacteria in the Simmon's citrate media lead to development of a blue colour (positive citrate) (Table 3 ) (Plate 2).

\section{Discussion}

TDS contents of different brands of water differed significantly $(p<0.05)$ from the standard level. TDS contents of all bottled water samples were lower than recommended level $(1000 \mathrm{mg} / \mathrm{l})$. The overall mean of TDS of 22 brands is lower than the SLS recommendation. Drinking water is normally expected to be without visible solids. These solids could be both organic and inorganic. The disadvantage of TDS is that they are aesthetically unacceptable. In addition, they harbour microorganisms, of which some are pathogenic. Further TDS may also impart palatability, colour and odour to water [3].

EC contents of different brands of water differed significantly $(p<0.05)$ from the standard level. EC contents of the bottled water samples were lower than recommended level $(750 \mu \mathrm{S} / \mathrm{cm})$. The overall mean of EC of 22 brands is lesser than the SLS recommendation. The $\mathrm{EC}$ of the water samples is an indicator of their salinity. A high value for electrical conductivity generally means a high degree of salinity and a low value shows that the salinity is low [12].

The $\mathrm{pH}$ value of different brands of water differed significantly $(\mathrm{p}<0.05)$ from the standard value (ranging from 6.5 to 8.5 ). The $\mathrm{pH}$ values of all the bottled water samples were lower than the recommended level (6.5 to 8.5). At $\mathrm{pH}$ levels above 8.5 , mineral incrustations and bitter tastes can occur. With $\mathrm{pH}$ levels above 8.5 , there is also a progressive decrease in the efficiency of chlorine disinfection and alum coagulation [3].

Calcium contents of all the bottled water samples were lower than the recommended level $(100 \mathrm{mg} / \mathrm{l})$. Nitrate contents of all the bottled water samples were lower than the recommended level $(50 \mathrm{mg} / \mathrm{l})$.

According to the Sri Lankan Standard $(894,2003)$, acceptable aerobic count is from $1 \times 10^{2}$ to $1 \times 10^{4} \mathrm{cfu} / \mathrm{mL}$. The aerobic bacterial counts of K, S, L and M; B, O, H and $\mathrm{N} ; \mathrm{R}, \mathrm{V}, \mathrm{P}, \mathrm{A}$ and $\mathrm{I}$ and $\mathrm{L}, \mathrm{C}, \mathrm{Q}, \mathrm{D}, \mathrm{U}$ and $\mathrm{T}$ brands were closely related to each other. The aerobic bacterial count of each of these groups significantly differed within themselves $(p<0.05)$. Most of the above bottled water brands contain aerobic bacterial count higher than the minimum recommended level by SLS while all the above brands contained lower bacterial count than the maximum level indicated by SLS. 
Based on Most Probable Number (MPN) table, different samples 1, 2 and 3 of the same brand $C$ had two normal coliform $/ 100 \mathrm{ml}$. But, samples 2 and 3 of brand C had two faecal coliform $/ 100 \mathrm{ml}$. Sample 1 of brand D had four normal and faecal coliform $/ 100 \mathrm{ml}$. Therefore, $1500 \mathrm{ml}$ of bottled drinking water $\mathrm{C}$ had 30 normal and faecal coliform and $1500 \mathrm{ml}$ of bottled drinking water $\mathrm{D}$ had 60 normal and faecal coliform. But, minimum range and maximum range of Sri Lankan standard for normal coliform is $0 / \mathrm{ml}$ and $10 / \mathrm{ml}$ respectively. Sri Lankan standard for E.coli is 0/ml (Sri Lankan Standard 894, 2003). Hence, the water samples $\mathrm{C}$ and $\mathrm{D}$ contained faecal coliform bacteria contamination. To find the faecal contamination in water, indole test was performed with non citrate utilizing strains and observed that only brand $\mathrm{C}$ had Escherichia coli and brand $\mathrm{D}$ might be having other faecal coliforms.

In conclusion more than half of the bottled drinking water brands in Jaffna peninsula were contaminated with aerobic bacteria. Three bottled drinking water brands had fungal contamination. Lack of knowledge about water quality, long storage period from manufactured date and higher environmental temperatures could be the reason for this high bacterial contamination of bottled drinking water.

\section{References}

1. Kawther F, Alwakeel S. Mineral and microbial contents of bottled and tap water in Riyadh, Saudi Arabia. Middle-East Journal of Scientific Research 2007; 3: 151-6.
2. Ikem A, Odueyungbo S, Egiebro NO, Nyavor K. Chemical quality of bottled waters from three cities in eastern Alabama. Science and Total Environment 2002; 285: 165-75.

3. Medema GJ, Payment P, Dufour A, et al. Safe drinking water: an ongoing challenge. In: Assessing Microbial Safety of Drinking Water. (Eds.) IWA publishing, UK, 2003: 11-36.

4. Misund A, Frengstad B, Siewer U, Reimann C. Variation of 66 elements in European bottled mineral waters. Science and Total Environment 1999; 243: 21-41.

5. Mahler RL, Colter A, Hirnyck, R. Nitrate and groundwater. 2007: http://info.ag.uidaho.edu/pdf/CIS/CIS0872.pdf. 2007.

6. Connerty HV, Briggs AR. Determination of serum calcium by means of orthocresolphthalein complexone. American Journal of Clinical Pathology 1966; 45: 290

7. Taras MJ. Nitrogen. In: Chemical Analysis. Calorimetric determination of non-metals, Ed. D. F. Bolts, New York: Inter Science Publishers Inc, 1958; 160-75.

8. Monica C. Medical Laboratory Manual For Tropical Countries, Tropical Health Technology, 14 Bevills Close, Doddington, Cambridgeshire, England, PE15 OTT, 1984: 40-58.

9. Levinson W, Jawetz E. Medical Microbiology and Immunology, McGraw-Hill, New York, 2000: 296-97.

10. Thevendrarajah K. Microbiology Laboratory Manual 1990: 8-33.

11. Sri Lankan Standard 894: Second revision (2003) Specification for bottled (packaged) drinking water. pp 5-7.

12. WHO (2004) Guidelines for Drinking Water Quality. Volume 1: Recommendations. 3rd edn, World Health Organization, Geneva. 